\title{
Research on the Construction Mode of Enterprise Colleges
}

\author{
Keyan Zhao \\ Liaoning Financial Vocational College, Shenyang 110122, China \\ Email: 570106000@qq.com
}

\begin{abstract}
A vocational college focuses on the training of high-quality technical personnel. The outline of the national plan for medium and long-term education reform and development clearly states that enterprises and other social forces should be encouraged to participate in running schools. Quality educational resources should be expanded, and the efficiency of running schools should be improved. The enterprise college can combine the superior resources of the enterprise and the superior resources of the college to promote the reform of the teaching mode of the college, to provide the society with high-quality skilled talents, and to improve the teaching quality of the college. Based on this, this article explores the construction mode of enterprise colleges, hoping to provide a reference for the reform of college teaching mode and make a contribution to the healthy development of colleges.
\end{abstract}

Keywords: enterprise college, teaching mode, technical personnel, personnel training

\section{Introduction}

Enterprise human resources is a pyramid structure model, so enterprises need a large number of strong technology, a strong sense of responsibility, and hard-working first-line technical personnel. However, the development process, core competitiveness and business philosophy will depend on talent requirements. Many enterprises in the recruitment of fresh graduates feel that the college's general model of students who are adapt to the corporate work environment also needs certain time. Therefore, enterprises need to invest a lot of time and cost to train talents after recruiting fresh graduates. And even if the enterprise is willing to spend time and capital to train new people, the training time of new people is longer, and they may be job-hopping, which will bring adverse impact to the enterprise. ${ }^{[1]}$ Therefore, more and more enterprises are beginning to realize that only by participating in the talent training process of the college in advance can the culture of the enterprise be integrated into the future enterprise talent-training, and can the passive become the active. The change of enterprise talent demand provides opportunities and conditions for the construction of enterprise colleges.

\section{The meaning and significance of enterprise colleges}

\subsection{The meaning of enterprise colleges}

An enterprise college refers to an integrated model of production, teaching and research adopted by a vocational college and an enterprise, which is based on a vocational education group and takes a specific specialty as an entry point, through the exchanges and cooperation in student training, enrollment, course teaching, teacher construction, training base construction, enterprise culture construction and so on. The colleges and enterprises take joint training as a tool in order to cultivate high-quality skilled personnel, improve the economic efficiency of enterprises and promote the common development of both sides.

The model of enterprise colleges has the characteristics of all-staff, all-process, all-round and integration ${ }^{[2]}$. Among them, the all-staff refers to all the members of the enterprise participating in the joint school model, including both the enterprise's top management and grass-roots staff. The all-process refers to the full participation of enterprises in the college's personnel training model, including the recruitment, training and later employment of students. The allround refers to the full participation of enterprises in the college's running and personnel training activities, including the selection of course contents, the construction of teaching staff and the construction of training bases, etc. Integration refers to the mutual integration between enterprises and colleges, and the participation of enterprises in college enrollment, course selection, the construction of training bases, employment and other activities. At the same time, the college also participates in the enterprise staff training, scientific research, technical services and other activities.

\subsection{The significance of the construction of enterprise colleges}

The construction of enterprise colleges is good for the transformation of the vocational education. Influenced by the thinking mode of planned economy, China's vocational education has been the product of "planning" for many 
years. Under the "planning model", the development logic of vocational education is the subjective value cognition of the government (or the scholars representing the government), but not the objective value pursuit of the enterprise. The establishment of the business college is the rational return of the value of the business vocational education, which shows the subjective demand of the vocational education of the business enterprise, and is beneficial to the "rebirth" of the vocational education. It is beneficial for the vocational education mode to turn from "planning mode" to "endogenous mode".

It's good to promote the development of vocational education characteristics. Whether the vocational education can train skilled talents to meet the needs of regional economic and social development, and highlight the characteristics and level of the vocational education, depends on whether we can "take the docking industry as the starting point, implement the cooperation between colleges and enterprises, work-study combination, the docking of specialty and industry, course content and professional standards, teaching process and production process, academic certificate and professional qualification certificate". Relying on the vocational education group, the college and the enterprise gather and optimize the resources, and organize the enterprise college with the related specialties which are connected with the industry as the carrier, to enhance the adaptability and pertinence, practicality and openness of personnel training, to improve the quality of personnel training and to promote the characteristic development of vocational education.

It is advantageous to construct the modern vocational education system. The basic features of modern vocational education system are to adapt to the transformation of economic development mode and the adjustment of industrial structure, to embody the idea of life-long education, and to coordinate the development of secondary and higher vocational education. An enterprise college established by a regional vocational education group is in conjunction with a vocational college for a relevant specialty, in accordance with the requirements of adapting to the transformation of regional economic development pattern and the adjustment of industrial structure, the organic connection of secondary and higher vocational education, and the multiple grade separation. The system design and scientific planning of the vocational education college-running mode is beneficial to link up the training program of the related specialty between the secondary vocational school and the higher vocational college in the region, and form the modern vocational education system with regional characteristics.

\section{The construction mechanism of enterprise colleges}

The goal of vocational education is to develop high quality skilled personnel with practical and operational skills to meet the needs of society. To achieve this goal, vocational education's teaching content should be closely aligned with industry's advanced technology, and the teaching process should focus on guiding students to perceive the real working environment. The enterprise college in the new era is different from the internal training organization which was set up in the early days based on the enterprise's own talent training angle. It is a secondary college set up in the higher vocational college, taking the college as the main body of educating people and giving full play to the enterprise's advantages. With specialty construction as the carrier, we will carry out deep cooperation in personnel training, enrollment and employment, teaching reform, double-division team construction, experimental training base construction and cultural construction. On the premise of mutual benefit, complementary advantages and shared resources, the establishment of a long-term and stable cooperative and educational relationship between the school and the enterprise conforms to the principle of the integration of production and education in vocational education, which is the return of the essence of vocational education under the guidance of demand. ${ }^{[3]}$ At the same time, the construction of a new type of enterprise college under the vision of Integration of industry and education, taking the enterprise as the main body of talent cultivation alongside the college, and receiving the training of order form in the enterprise, can meet the lifelong learning needs of enterprise employees, so that the two sides really realize the benefits of sharing, complementary advantages, and joint construction. According to the different training objects, the enterprise colleges in the new era can be divided into three types. One is to train full-time students. The second is to pay equal attention to full-time training and employee training. The third is the enterprise staff training and academic training.

The enterprise college can solve the contradiction of the separation of production and education in vocational education. The construction of an enterprise college means giving full play to the advantages of the enterprise as the main body of the vocational education, under the guidance of policy and the guidance of the college, from the policy support, the talented person output, the technical innovation, and the cultural production, which stimulate the enterprise to participate in the enthusiasm, cause the enterprise to assume the vocational education main body responsibility positively, and devote to the innovation skill talented person training together. Both the college and the enterprise carry out cooperative education around a certain specialty or specialty group to realize the deep integration of production and teaching. On the one hand, 
unlike enterprises which unilaterally run factory schools, enterprises can fully integrate into the whole process of running schools. It will provide educational assistance in the areas of enrollment and employment, course setting, teaching reform, construction of teaching staff, experimental and training bases and construction of school culture. On the other hand, vocational colleges will also be fully integrated into enterprises, in product development, technology promotion, staff training, research and other aspects of enterprise development to provide innovative power.

\section{Characteristics of construction mode of enterprise colleges}

The reform and development of vocational education ushered in the spring of a hundred flowers in full bloom during the crucial period of winning a decisive victory in building the Xiaokang in an all-round way and embarking on a new journey of building a modern socialist country in an all-round way. In the new era, new changes have taken place in the basic elements of the vocational education, which has endowed the enterprise college with distinctive features of the times. It is embodied in "one $f u$, three jiaos and five xues". ${ }^{[4]}$

First, "one $f u$ " is to establish the concept of education for the development of students. The basic task of the enterprise college is to "establish morality and cultivate people". That is to train artisans in the big socialist countries with all-round development of morality, intelligence, physique, art and labor. Therefore, we should pay attention to students' needs in the process of college and enterprise, so as to make learning more personalized and targeted, and realize demand-oriented, effective service and accurate education.

Second, "three jiaos" is "teaching staff, teaching content, teaching methods" in enterprise colleges endowed with new characteristics by the new era. The first is the construction of a diversified teaching staff. Enterprise technicians, industrial craftsmen and theoretical teachers in colleges and universities will jointly teach, multi-teacher, and collaborative teaching, to provide curriculum services guided by the needs of students, to form effective teaching inspiration, and to achieve the optimal allocation of teaching resources. The second is the teaching content information. Information era calls for knowledge information symmetry, students need diversified knowledge and skills. Classroom teaching is not the whole of education and teaching, campus culture, enterprise culture, scientific research culture, technological innovation culture, cultural and sports activities will become the important needs of students. New knowledge, new technology and new materials are changing with each passing day. The times also put forward new requirements for teaching materials. The third is the teaching method individualizes. The teaching methods of the new era should aim at satisfying the students' individualized learning needs and encourage teachers to make individualized learning plans for students in the form of fixed "course package" and characteristic "service package". We should attach importance to situational learning, blended learning and task-based learning, take interest as drive, activity as support and competition as guide, and pay attention to cultivate students' study habits, so as to arouse students' study enthusiasm and improve their study effect.

Third, "five xues" is students, school system, school status, learning style, credits. With the expansion of higher vocational colleges in 2019, the student population has changed. Veterans, laid-off workers, migrant workers, newtype professional farmers ${ }^{[5]}$ and so on are all likely to become students, which drives the changing of the school system, hours, credits, learning methods. As vocational education enters the liberal education stage, the study of professional courses is not only the teaching of knowledge and technology, but also the teaching of professional culture, value culture and life style. The study time of higher vocational students is limited. How to make them study the key knowledge, the system knowledge, the core technology and become the "professional person"? It needs to have the overall grasp to the curriculum, forms the knowledge system, and grasps the core curriculum, the core ability. At the same time, it is necessary to cultivate students' interest and motivation, so that students of different levels and different personalities can learn through experience and participation.

\section{The way to construct the mode of enterprise colleges}

\subsection{Clarify power and responsibility to realize characteristic development}

It is the essential attribute of the enterprise college to take educating people as the basic task and persist in running the college for public welfare. The ultimate aim of running a business college is to cultivate innovative talents for the industry and enterprises, and to promote the innovation of the industry technology reform. There is no denying that enterprises need to make profits, and the interest demand of enterprises is the fundamental motive force for enterprises to participate in college-enterprise cooperation. Therefore, colleges should be open-minded, face the collision and conflict between the college and enterprise culture, fully consider the reasonable returns of enterprises, and clarify the responsibilities, rights and interests of both sides under the premise of insisting on running schools for public welfare and cultivating talents. 
At the same time, both sides actively communicate with enterprises, promote the long-term comprehensive benefits of enterprise participation, protect the enthusiasm of enterprise participation in education. In the construction of enterprise college, we should stress the feature of "double main body", and realize the equality of rights and obligations between college and enterprise. While paying attention to the reform of "horizontal integration" in the cultivation of talents, we should stick to the single subject of "vertical integration" in the goal of college education, and give full play to the complementary advantages of colleges and enterprises, in line with the new era of integration of industry and education, collaborative education of new trends, and new requirements.

\subsection{Make clear the selection criteria of cooperative enterprises to promote the sustainable development of college-enterprise cooperation}

The first problem to be solved in the construction of enterprise college is to make clear the selection criteria of the cooperative enterprise. That is, to choose what kind of enterprise to cooperate with to build the secondary college. The students trained by the enterprise college should reach or lead the advanced level of the industry, and the cooperative enterprise must be in the leading level in the industry. Therefore, when choosing the enterprise cooperation to build the enterprise college, the college should take into full consideration of the enterprise's initiative in running the school, the interest demand, the scale of development, the right to speak in the industry, the superiority of personnel resources and other comprehensive factors. Choosing enterprises with strong will run a college, large scale and strong strength. At the same time, the identity of the college to the corporate culture is very important. The cooperative college should choose the enterprise which is committed to serving and giving back to the society and has a higher sense of social responsibility. The identity of both sides in values can move the conflict of interests forward and help to reduce unnecessary friction and contradiction. In order to promote the sustainable development of school-enterprise cooperation, the long-term effectiveness of cooperation should be paid attention to in the construction of enterprise college. In running a school in cooperation, we should not only meet the needs of enterprises for talents, but also pay attention to and solve the contradiction between the needs of enterprises for talents and students' career development, so as to avoid the enterprise college becoming a training institution. At the same time, the state should strengthen the construction of industrial organizations, formulate industrial standards, change the behavior of "peer-to-peer" cooperation between colleges and enterprises, and organize colleges and enterprises groups to carry out "peer-to-peer" cooperation.

\subsection{Strengthen cooperation between colleges and enterprises to educate students cooperatively}

The construction of cooperative education mechanism is the guarantee of opening the cooperation between school and enterprise and the integration of industry and education. For the dual college-running bodies of colleges and enterprises, through the joint formulation of talent training programmes, the joint reform of enrollment methods, the joint improvement of the curriculum system, the joint reform of teaching models, the joint reform of teaching evaluation methods, the joint construction of teaching and management teams and the joint construction of teaching and scientific research training bases, we should construct "seven common" of school-enterprise cooperation in educating people. ${ }^{[6]}$

First, jointly developing a talent training program. According to the national professional teaching standards (for trial implementation), both the college and the enterprise follow the idea of "student-apprentice-employee" trinity and "ability core, systematic training, post talent". According to the requirements of enterprise talents and the students' own development needs, we discuss and formulate the talent training plan together. On this basis, the curriculum standards, master (teacher) standards, quality control standards and implementation program, fully reflect the college-led, student participation.

Second, we should reform the way we recruit students. The first is relying on the "dual system" talent training model reform project to achieve "recruiting is recruiting students". For employees who have signed a formal contract, the use of basic knowledge test and staff post skills test separate recruitment test method form a "dual system" talent training class $^{[7]}$.The second is relying on the modern apprenticeship training model reform projects, to achieve "recruitment is recruitment". The college and the enterprise jointly draw up the selection plan adopt the methods of interview, on-the-spot ability examination and so on. The enterprise and the college jointly carry out the apprentice selection work, and set up the modern apprentice system talented person training class. And by signing the tripartite agreement among the college, the enterprise and the students clarify the rights and obligations of the three parties.

Third is building the curriculum system together. Based on the working process, the college and the enterprise jointly construct the curriculum system embodying the ability standard and the professional practice, use the work task to lead the study of the professional knowledge, and use the production of the enterprise typical products to lead the formulation of the project curriculum content by the enterprise to provide students with a real internship environment. The college 
and enterprise double tutors jointly construct high-quality core courses, fine online open courses, professional teaching resources, develop the college and enterprise "dual" training characteristic teaching materials, and effectively realize the integration of curriculum and certificate.

The fourth is reforming the teaching mode together. Through the implementation of industry enterprises "double" teaching, the implementation of a variety of teaching methods and the reform of classroom teaching mode. In the teaching method, we should focus on learners, encourage group learning, project learning and cooperative learning, and advocate the "three-action teaching" of "using head, mouth and hands". We should push forward the innovation of the teaching mode of the key teachers team, the famous teachers studio or the Master Studio, and the professional leaders, break through the bottleneck of the students' professional training, so as to arouse and stimulate the students' interest and initiative in learning, and improve the learning effect.

The fifth is reforming the teaching evaluation mechanism together. Colleges and enterprises jointly establish quality control system, improve teaching evaluation methods, the implementation of day, week, month exchange, quarterly commendation, period summary, appraisal and other process assessment. ${ }^{[8]}$ The establishment of schools, industries, enterprises to participate in multiple subjects, teachers and students bundled assessment system. To show the work, competition award, defense report, professional qualifications or skills level certificate to replace the traditional assessment methods, focus on the process and ability of assessment, personalized training.

The sixth is jointly building the teaching and management team. Enterprise and colleges implement the mechanism of "double professional leaders" and "double deans". Colleg-enterprise cooperation in the construction of professional teachers and student management team improves service teaching, with a view to improving the overall teaching effect and the quality of personnel training. Specifically speaking, the first is the construction of professional teaching staff, mainly by the college "double-qualified" professional teachers and enterprise management technical staff. The second is to build a student management team, composed of college secretaries and counselors and senior managers of human resources in enterprises, to implement the management of double-class directors, who are respectively responsible for the management of "dual system" students on campus and in enterprises. Students will be organized to participate in the cultural activities and skills competitions of the colleges associations, so as to realize the enterprise culture entering the campus and the campus culture entering the mind, and to create a multi-cultural education pattern together.

The seventh is jointly building the "three-in-one" base. Based on the carrier of teaching, scientific research and practical training, and through cooperation with enterprises in building talent centers, teacher training and scientific research incubation bases, enterprise teaching bases, productive training bases in colleges, "factories in schools" and "factories in schools", are helpful to realize the joint construction and sharing of schools and enterprises, to carry out staff training, and to provide software and hardware support for external services. The function of "five-in-one" includes practice teaching, skill assessment, training and appraisal of enterprise staff, student skill competition and R \& D service.

\subsection{Build platforms to facilitate integration}

The mode of enterprise college mainly includes talent training scheme into campus, teachers into campus, enterprise culture and operation mode into campus, practical teaching platform, collaborative innovation platform and employment and entrepreneurship service platform.

Talent training program into the campus means, according to the needs of industry development, colleges and enterprises should work out the educational mechanism of integration of production and education and co-education based on the principle of resources co-construction, mutual benefit and win-win, and common development, to determine the mode of personnel training and the evaluation standard of professional ability.

Teachers entering campus means colleges and enterprises jointly establish "double-qualified" teacher training center and establish "mutual evaluation, mutual training and mutual engagement" colleges teachers work part-time in enterprises to enhance project development, engineering experience and understanding of corporate culture and business operation model. Enterprise engineers through college training improve the level of classroom teaching to jointly develop teacher training business for teachers of cooperative enterprises and teachers of social-related specialties.

The enterprise culture and the operation pattern enters the campus means fully utilizing the enterprise internationalization, the informationization skill competition platform and the rich competition organization experience, facing the cooperation specialized student to organize the specialized skill competition, and through the skills competition to stimulate students to professional love and interest in learning for employers to select talent.

Practical teaching platform means carrying out freshmen enrollment education, cognitive practice, curriculum design, professional courses teaching, professional training, graduation design, post practice, and other cooperation. 
Collaborative innovation platform means that by building collaborative innovation platform, colleges and enterprises can drive innovation in concept, technology, mode and mechanism on both sides of colleges and enterprises, and by jointly developing the application and R \& D of scientific research projects and industrial projects, transformation of scientific and technological achievements, teaching and research activities, to undertake local information construction projects, efforts to create social and economic value, serve local economic development.

Employment and business start-up service platform means that enterprises use the employment channels they have established over the years to set up online and offline employment service platforms, and set up student employment service bases in the locations of enterprises and colleges respectively, and provide career guidance to students. According to the needs of the college, the enterprise organizes the employing units to carry out the special recruitment activities for fresh graduates on the campus.

\subsection{Construct guarantee system to promote healthy operation}

Mechanism, organization, system and fund are the four basic guarantees for the operation of the enterprise college. We should pay attention to the construction of the "four-dimensional integration". Operation guarantee system provides strong guarantee for the smooth operation of the enterprise college. First, we should establish a flexible mechanism for multiparty participation, build a deeply integrated enterprise college, sign a tripartite agreement with a contractual joint venture, and clarify the status of apprentices and the rights and obligations of colleges, enterprises and apprentices ${ }^{[10]}$. Second, we should set up a complete organizational structure and set up a leading group for the "double-main-body" personnel training of colleges and enterprises, which will be composed of school principals, executive directors of enterprises, heads of teaching and functional departments of colleges and heads of enterprise departments, etc. Depending on the second-level College, the enterprise college carries out the system of "two deans" and "two professional leaders". Third, the introduction of a supporting system to provide funding support. By formulating and implementing such institutional documents as the measures for the management of the faculty, the measures for the management of students, the measures for the management of teaching and the measures for the evaluation of the quality of the "dual" personnel training in colleges and enterprises, we provide the system guarantee for the reform of the "dual" training mode of school and enterprise. Through setting up the special fund of the reform project of the school-enterprise double-main body, introducing the fund of the joint construction of the enterprise, implementing the special fund management method of the specialty construction of the enterprise college, we provide the fund guarantee for the cultivation of the talents of the college-enterprise double-main body.

\section{References}

[1] Shao Liqun, Ni Bijun. Exploration and practice of collaborative education of enterprises and colleges under the background of integration of industry and education - taking SIIT as an example. Journal of Adult Education. 2020; (1): 45-48.

[2] Cheng Xiuping, Tang Xiangjin. Talents' Cultivation Deeply Cooperated by Business School \& Its Guarantee Mechanism. Journal of Taizhou Polytechnical College. 2018; 18(5): 9-12+35.

[3] Tang Xiangjin. An Innovative Practice of Educating Talents by the Working Committee for the Care of the Next Generation with the Help of Enterprises and Colleges: a Case Study of SIIT. Journal of Suzhou Vocational University. 2017; 28(1): 55-59.

[4] Tang Xiangjin. Research on Innovative Practice of Deep Cooperative Education in Enterprise Colleges: a Case Study of Tongcheng Tourism School of Suzhou Vocational Institute of Industrial Technology. 2019;17(5): 126-129.

[5] Zhou Le, Li Ting, Zhou Yongxin. University-enterprise integration and the cooperation mechanism of business college — taking the construction of enterprise college of Jiaxing Vocational and Technical College as an example. Data of Culture and Education. 2018; (5): 133-134+149.

[6] Liu Xiaomei, Feng Chaoyin. Research and practice of the school-enterprise integrated education model based on "enterprise college" in higher vocational colleges - taking Haitian College of Architectural Decoration of Xuchang Vocational and Technical College as an example. The Guide of Science \& Education. 2019; (9): 20-21.

[7] Li Ming, Gou Xiaomei, Zhang Yun. Exploration and Practice of Interior Design Talents Training Mode Based on "Enterprise Institute". Journal of Wuhan Polytechnic. 2017; 16(6): 30-33.

[8] Tang Xiangjin. The "Five Teachings in One" Educational Model of Deep Collaboration in Enterprise Colleges Taking the "Tongcheng Tourism College" of Suzhou Industrial Vocational and Technical College As an Example. Vocational and Technical Education. 2018; 39(2): 20-22.

[9] Cheng You'eResearch and Practice of Enterprise Internship Management Based on "Five Hua" — Taking Zhejiang 
Industry and Trade Vocational and Technical College As an Example. Chinese Vocational and Technical Education. 2019; (11): 81-86

[10] Zhang Xinghui. Research on the Effect and Influencing Factors of Enterprise Internship of "Excellent Engineer Education and Training Program" - Taking the School of Aeronautical Engineering of Civil Aviation University of China As an Example. Journal of Inner Mongolia Normal University. 2019; 32(4): 17-24. 